\title{
Kepercayaan (Trust) Pada Komunitas Nelayan Pulau Bontosua Kabupaten Pangkep
}

\author{
Trust in the Fisherman Community Bontosua Island, Pangkep District \\ Sakaria $^{1}$; Suparman ${ }^{2}$; Muhammad Basrun ${ }^{3}$; Surianti ${ }^{4}$; Nirwana Indah ${ }^{5 *}$ \\ 1.2. Departemen Sosiologi, Fakultas Ilmu Sosial dan Ilmu Politik Universitas Hasanuddin \\ Email Coresponden: sakaria_anwar_ipb@yahoo.com ${ }^{\text {; }}$; mansosio87@yahoo.com ${ }^{2}$
}

\section{A R T I C L E I N F O}

\section{How to Cite: \\ Sakaria, Suparman, Basrun, M., Surianti, \& Indah, N. (2019). Kepercayaan (Trust) Pada Komunitas Nelayan Pulau Bontosua Kabupaten Pangkep. Hasanuddin Journal of Sociology (HJS), 1(2), 155- 167.}

\section{Keywords: \\ Social capital, social resources, trust (trust), fishing communities.}

\section{Kata Kunci :}

modal sosial, sumber daya sosial, kepercayaan (trust), komunitas nelayan.

\begin{abstract}
A B S T R A C T
Social capital is a social resource that has forming elements found in a society or community. This paper discusses the social capital of the fishing village community of Mattiro Bone Bontosua Island from the aspect of trust. This study uses a mix method in which data collection uses qualitative methods and quantitative methods. Data collection was carried out through in-depth interviews and limited observations from five informants determined by snowball sampling. In addition, the questionnaire was also distributed to 15 respondents. Then the data were analyzed qualitatively to explain the research data and facts. The results showed that the trust (trust) of the fishing village community of Bontosua Island is still relatively high, this is evidenced by the data such as the level of trust between residents / neighbors, trust in the village government and community leaders is still relatively high.
\end{abstract}

\begin{abstract}
ABSTRAK
Modal sosial merupakan sumber daya sosial yang memiliki elemen-elemen pembentuk yang terdapat dalam suatu masyarakat atau komunitas. Tulisan ini membahas tentang modal sosial masyarakat desa nelayan Mattiro Bone Pulau Bontosua dari aspek trust (kepercayaan). Penelitian ini menggunakan mix method dimana pengumpulan data menggunakan metode kualitatif dan metode kuantitatif. Pengumpulan data dilakukan melalui wawancara mendalam dan observasi terbatas dari lima informan yang ditentukan secara snowball sampling. Selain itu kuesioner juga disebar ke 15 responden. Kemudian data dianalisis secara kualitatif untuk menjelaskan data penelitian dan fakta. Hasil penelitian menunjukkan bahwa kepercayaan (trust) masyarakat desa nelayan Pulau Bontosua masih tergolong tinggi, hal ini dibuktikan oleh data antara lain seperti tingkat kepercayaan antar warga/tetangga, kepercayaan kepada pemerintah desa dan tokoh masyarakat masih tergolong tinggi.
\end{abstract}




\section{PENDAhuluan}

Sulawesi Selatan sebagai salah satu daerah yang memiliki luas perairan laut cukup besar menjadikan hasil komoditi laut sebagai salah satu andalan dalam pendapatan asli daerah Sulawesi Selatan. Potensi perikanan dan kelautan meliputi panjang garis pantai $2.500 \mathrm{~km}$, perikanan laut 600.000 ton/tahun, perairan umum 40.000 ton/tahun, budidaya tambak 150.000 ha, budidaya air tawar 100.000 Ha dan areal budidaya laut 600.000 Ha yang terdapat di Propinsi Sulawesi Selatan. Salah satu potensi perikanan dan kelautan yang dimiliki oleh Sulawesi Selatan adalah potensi ekspor telur ikan terbang dimana tercata pada tahun 2010 ekspor telur ikan terbang berdasarkan Dinas dan Kelautan dan Perikanan Provinsi Sulawesi Selatan (2014) adalah sebesar 600.870 ton (Mustafa, 2015).

Komunitas nelayan memiliki sejumlah potensi, khususnya modal sosial yang membuat warganya dapat bertahan hidup bahkan berkelanjutan sesuai dengan tuntutan kebutuhan masa kini. Proses-proses sosial yang berlangsung selama ini mencerminkan kuatnya modal sosial yang dimiliki oleh komunitas. Modal sosial tersebut dapat dilihat dari system kerja, hubungan sosial dan aktivitas sosial lainnya. Seperti komunitas nelayan memiliki kesadaran kolektif yang tinggi, karena system kekerabatan yang ada yang mencerminkan bahwa komunitas nelayan dibangun karena mata pencaharian dan juga oleh ikatan darah dan perkawinan. Komunitas nelayan memiliki system nilai (kearifan local), system religi (agama dan kepercayaan) dan sistem kerja (mekanisme dan cara) dalam pemenuhan kebutuhannya.

Setiap komunitas memiliki sumber dan potensi modal sosial yang bermanfaat untuk kontribusi dalam pencapaian tujuan bersama. Potensi modal sosial tersebut dalam suatu masyarakat atau komunitas merupakan sumber bagi terciptanya keharmonisan sosial. Sebagai bagian dari sumber daya lokal, modal sosial merupakan aset nyata yang penting dalam hidup bermasyarakat. Coleman menyatakan bahwa modal sosial bukan merupakan sebuah entitas (entity) tunggal tetapi berbagai macam entitas yang berbeda, dengan dua elemen bersama: terdiri dari beberapa aspek struktur sosial, dan memfasilitasi tindakan pelaku-pelaku tertentu dalam struktur itu. Tidak seperti bentuk modal lain, modal sosial melekat dalam struktur hubungan antara para pelaku dan diantara para pelaku (Coleman, 1988)

Struktur modal sosial komunitas nelayan dapat di kategorikan kedalam empat unsur, salah satu di antaranya adalah kepercayaan (trust). Kekuatan modal sosial trust merupakan salah satu tumpuan bagi terlaksananya beragam kegiatan dalam suatu masyarakat atau komunitas yang didasarkan pada saling percaya antar masyarakat. Modal sosial trust ini merupakan media komunitas nelayan dalam memperkokoh persatuan masyarakat nelayan di Desa Mattiro Bone dalam bermasyarakat. 
Menurut Santosa (2014), trust atau kepercayaan merupakan salah satu elemen modal sosial yang berfungsi sebagai pelumas yang sangat efektif bagi jalinan kerjasama kolektif. Kepercayaan berhubungan dengan kejujuran dan kerja sama yang ada di antara orang-orang dalam sebuah komunitas. Seseorang berpikiran bersedia untuk bekerja sama jika ia percaya bahwa anggota kelompok lainnya akan bekerja sama juga. Untuk mendapatkan kerjasama, tidak cukup hanya dengan memiliki timbal balik, orang-orang harus percaya orang lain akan bekerja sama.

Konsep kepercayaan sangat penting dalam penelitian modal sosial. Kepercayaan merupakan suatu bentuk keinginan untuk mengambil resiko dalam hubungan sosial yang didasari oleh perasaan yakin bahwa yang lainnya akan melakukan sesuatu seperti yang diharapkan dan akan bertindak dalam pola tindakan yang saling mendukung. Tindakan kolektif yang di dasari oleh rasa saling percaya yang tinggi akan meningkatkan partisipasi masyarakat.

Secara sosiologis, dapat dikemukakan bahwa komunitas nelayan memiliki karakteristik yang khas dan berbeda dari masyarakat lain, seperti masyarakat petani, masyarakat urban, dan sebagainya. Masyarakat atau desa nelayan merupakan suatu komunitas yang memiliki pola-pola interaksi dan pola budaya yang berbeda sebagai hasil interaksi mereka dengan lingkungan alamnya beserta segala sumberdaya yang ada di dalamnya, yaitu wilayah laut. Pola-pola interaksi dan budaya itu menjadi referensi berperilaku masyarakat nelayan dalam menjalani kehidupannya.

Sehubungan dengan adanya interaksi yang dinamis antara komunitas nelayan dengan lingkungan tempat tinggalnya dapat menimbulkan suatu bentuk aktivitas atau kegiatan, dan sekaligus membentuk adanya pranata-pranata sosial yang berfungsi untuk memenuhi kebutuhan khusus dalam masyarakat nelayan. Berkembang tidaknya pranata sosial akan sangat tergantung dari dinamika aktivitas yang terjadi pada masyarakat nelayan. Adapun bentuk aktivitas sebagai hasil interaksi masyarakt nelayan dengan lingkungannya akan menimbulkan perubahan, baik itu perubahan perkembangan, perubahan lokasi, dan perubahan perilaku.

\section{METODE PENELITIAN}

Penelitian ini menggunakan metode penelitian gabungan (mix method) yakni penelitian dengan menggabungkan dua metode pengumpulan data hasil penelitian yakni metode kualitatif dan kuantitatif dimana lokasi penelitiannya di Desa Mattiro Bone, Pulau Bontosua, Kabupaten Pangkep. Pengumpulan data dilakukan melalui wawancara mendalam dan observasi yang terdiri dari lima informan yang ditentukan secara snowball sampling, dan juga penyebaran kuesioner ke 15 responden. Kemudian data dianalisis secara kualitatif untuk menjelaskan data penelitian dan fakta. 


\section{HASIL DAN PEMBAHASAN}

\section{- Konsep Modal Sosial}

Konsep modal sosial pertama kali ditemukan oleh Coleman yang didefinsikan sebagai aspekaspek dari struktur hubungan antara individu yang memungkinkan mereka menciptakan nilai-nilai baru. Lebih lanjut, Coleman membedakan antara modal sosial dengan modal fisik dan juga modal manusia. Dari berbagai hasil kajian terhadap proyek pembangunan di dunia ketiga, menurut Ostrom (1992), menyimpulkan bahwa modal sosial merupakan prasyarat bagi keberhasilan suatu proyek pembangunan.

Aspek kepercayaan atau trust merupakan unsur yang sangat esensial di dalam membentuk modal sosial, oleh karena kepercayaan merupakan elemen utama dari modal sosial. Dalam hal ini modal sosial dipahami sebagai pengetahuan dan pemahaman yang dimiliki bersama komunitas atau masyarakat, serta pola yang memungkinkan sekelompok individu melakukan suatu kegiatan produktif. Modal sosial merupakan suatu komitmen dari setiap individu untuk saling terbuka, saling percaya, memberikan kewenangan bagi setiap orang yang dipilihnya untuk berperan sesuai dengan tanggungjawabnya (Mawarni, 2010).

Fukuyama mengupas pentingnya modal sosial berbasis pada kepercayaan. Dalam keseharian, masyarakat berinteraksi dengan modal sosial yang kuat yang ditunjukkan dengan suasana saling percaya antarwarga. Bentuk modal sosial inilah yang memiliki hubungan erat dengan tercapainya tingkat kesejahteraan masyarakat atau bangsa.

\section{- Kepercayaan (Trust) Antar Warga Desa}

Kepercayaan (trust) antar warga merupakan salah satu bagian penting yang menentukan keharmonisan hubungan sosial antar warga dan sekaligus dapat menjadi salah satu modal bagi kemajuan masyarakat atau suatu komunitas. Seperti dikemukakan Fukuyama bahwa dalam masyarakat yang tingkat kepercayaan (trust) antar warganya sangat tinggi (hight trust) umumnya lebih cepat maju dibanding masyarakat yang tingkat kepercayaan (trust) antar warganya rendah (low trust). Karena terbentuknya kepercayaan (trust) antar warga dalam suatu komunitas akan memudahkan terjadinya kerja sama yang kemudian membentuk jaringan di dalam (intra) maupun di luar (extra) komunitasnya. Untuk mengetahui kepercayaan (trust) antar warga di Desa Mattiro Bone, peneliti menganalisis data antara lain persepsi warga mengenai; keyakinan warga akan keamanan rumahnya jika ditinggal pergi beberapa hari, keyakinan warga bahwa tetangganya adalah orang yang baik, keyakinan warga bahwa komunitas pulau pada umumnya adalah orang yang jujur, kesediaan menerima pendatang tanpa melihat 
latar belakang sosial-budayanya.

Hasil penelitian menunjukkan bahwa warga di Mattiro Bone sangat yakin bahwa rumahnya akan aman dan diawasi tetangga jika ditinggalkan pergi untuk beberapa hari. Dari data tersebut dapat pula dijelaskan bahwa jika warga hendak bepergian mereka sangat yakin rumahnya akan aman karena tetangganya akan mengawasi. Jadi dalam hal ini ada kaitan antara keamanan rumah warga dengan keterlibatan tetangga dalam pengawasan. Pengawasan tetangga terhadap rumah yang ditinggalkan pergi pemiliknya untuk beberapa hari biasanya dilakukan dengan cara salah satu anggota rumah tangga warga dimaksud menginap di rumah tersebut pada malam hari. Sementara pada siang harinya cukup memantau saja dari rumahnya, karena memang suasana pulau masih sangat aman dari hal-hal yang berbau tindakan kejahatan seperti pencurian. Hal ini semuanya dilakukan oleh tetangga sebagai bukti tanggung jawabnya bagi keamanan rumah dan harta tetangganya yang sementara ada urusan.

Seperti yang dinyatakan oleh seorang informan berinisial (M):

"Istri saya orang Sidrap biasanya kita pergi ke kampungnya untuk silaturahmi, kalau kita pergi na rumah kosong biasanya saya minta tolong sama tetangga untuk jaga rumahku. Tapi biar begitu sebenarnya tidak masalahji ditinggalkan rumah karena percaya maki sama tetangga, tidak bakalanji ada yang mau sembarang masuk di rumah. Kita percaya warga disini orangnya jujur, apalagi rata-rata disini saling berkeluargaji warganya”. (Wawancara, 20 mei 2017).

Keyakinan warga terhadap keamanan dan pengawasan rumah mereka dari tetangga jika ditinggal pergi dalam beberapa hari. Menurut mereka tetangga yang baik adalah tetangga yang saling peduli dan mau membantu satu sama lain misalnya turut mengawasi keamanan rumah tetangga saat ditinggal pergi. Hal ini telah menjadi nilai bersama bagi warga sampai akhirnya kondisi tersebut berubah seiring dengan perkembangan dan kemajuan komunitas pulau melalui pelaksanaan program pembangunan yang diikuti oleh komersialisasi hasil laut yang dihasilkan oleh warga pulau.

Kejujuran bagi warga pulau Bontosua merupakan modal penting yang harus dimiliki oleh setiap orang agar dapat dipercaya oleh warga lainnya. Itulah sebabnya warga Pulau Bontosua menjadikan kejujuran sebagai nilai yang harus terus dipelihara agar dapat bertahan dalam kehidupan bermasyarakat pada komunitas pulau. Sebab melalui kejujuran seseorang akan terbangun kepercayaannya (trustnya) kepada warga yang bersangkutan.

Seperti yang dinyatakan oleh informan berinisial (R), yang menyatakan bahwa:

"Semua warga di disini jujur. Biasanya saya tidak pernah kunci rumahku kalau malam saya juga punya warung tapi tidak kukunci cuma di tutupji. Tidak masalahji biar tidak dikunci karena percaya maki sama warga yang lain tidak bakalanji ada yang berani ambil barang yang bukan punyanya. Apalagi selama ini, tidak pernahji terjadi ada warga yang kecurian rumahnya”. (Wawancara, 20 mei 2017). 
Karakteristik Desa Mattiro Bone yang homogen dan di dominasi oleh masyarakat pendatang dari makassar menjadikan Desa Mattiro Bone jarang berkembang isu-isu yang meresahkan warga. Rasa saling memiliki dan seperjuangan sama-sama dari daerah juga menjadikan desa ini memiliki trust yang baik dalam hubungan dan kerukunan warga. Walaupun tidak kita pungkiri isu-isu ketidaksukaan juga pasti ada.

Kehadiran para pendatang dan adanya pengalaman yang didapatkan oleh warga pulau setelah bepergian telah merubah cara pandang dan pola pikir komunitas pulau terutama mengenai aspirasi hidup, bahwa hidup harus berubah secara materi misalnya memiliki rumah yang bagus dengan perabot rumah tangga yang bagus. Atas dasar itulah membuat warga pulau semakin sibuk bekerja guna menambah pendapatan mereka agar dapat memiliki rumah yang bagus dengan perabot yang bagus pula. Dan semangat kerja keras warga pulau telah membuahkan hasil sebagaimana saat ini terlihat bangunanbangunan rumah yang tidak kalah dengan di kota.

Sejalan dengan data di atas, dalam wawancara seorang informan $(\mathrm{H})$ mengemukakan sbb:

"Kita sebagai warga masyarakat di Bontosua, rasa saling percaya antar warga masih tetap terjaga sampai saat ini', karena saya rasa sudah seperti keluarga sendiri apalagi kita disini sudah lama tinggal dan saling mengenal". (Wawancara, 20 mei 2017).

Hasil yang menunjukkan bahwa adanya hubungan tingkat kepercayaan yang tinggi antar warga di Pulau Bontosua ini dapat dilihat dari hasil pengisian kuesioner yang telah diisi oleh responden, hasilnya dapat dilihat dalam diagram berikut ini:

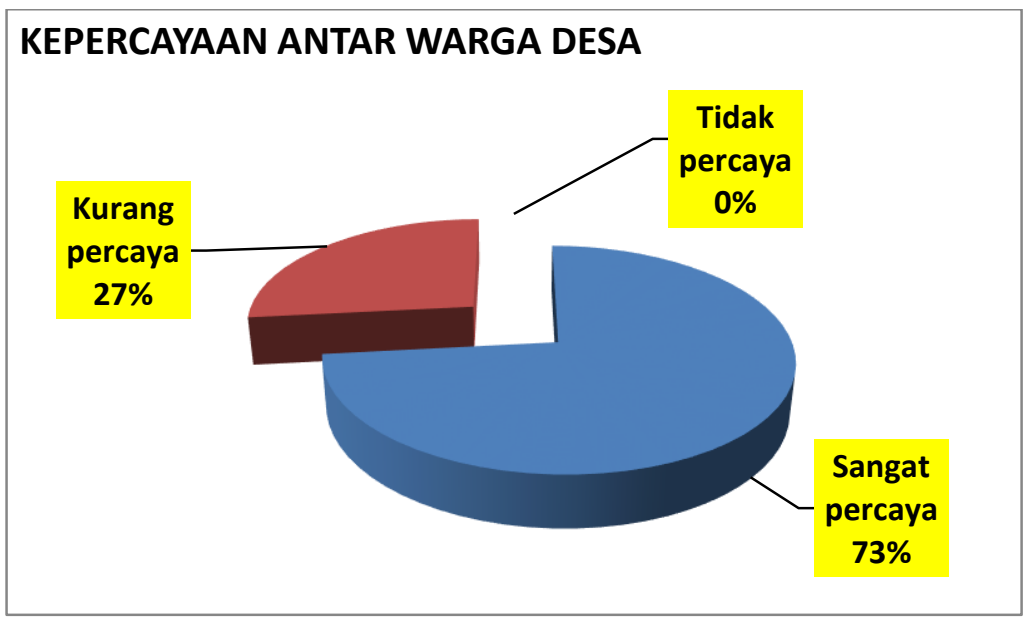

Diagram 1. Tingkat Kepercayaan antar Warga

Diagram diatas menjelaskan bagaimana tingkat kepercayaan antar warga di Desa Mattiro Bone 
yang melalui beberapa variabel antara lain: sikap saling menghargai, tolong-menolong, dan kejujuran dari masing-masing warga. Berdasarkan data pada diagram diatas terlihat jelas bahwa dari 15 responden yang berpartisipasi sebanyak $73 \%$ diantaranya menyatakan jika warga saling percaya satu sama lain. Ini menunjukkan bahwa tingkat kepercayaan warga Desa Mattiro Bone terhadap warga lainnya sangat tinggi. Adanya sikap saling percaya antar warga Desa Mattiro Bone tidak terlepas dari adanya beberapa faktor yang dimiliki bersama oleh warga bersangkutan diantaranya; kejujuran, kebaikan, saling menghargai, dan saling tolong menolong.

\section{- Kepercayaan (Trust) Terhadap Pemerintah Desa dan Tokoh Masyarakat}

Menyangkut kepercayaan kepada pemerintah desa, informan umumnya menaruh kepercayaan. Mereka yang sudah dipilih untuk menjalankan roda pemerintahan sebagai perangkat desa pasti memiliki tanggung jawab terhadap program pembangunan yang dilakukan di desa untuk kemajuan masyarakat desa.Informan sangat percaya dengan kerja yang menjadi tanggung jawab dari pemerintah desa, baik yang berkaitan dengan program/proyek maupun kepemimpinan di desa, karena menurut informan selama ini tidak pernah ada keberatan dari masyarakat atau penolakan terhadap kinerja yang dilakukan oleh pemerintah desa. Semua program yang dilakukan pemerintah desa juga adalah untuk kepentingan masyarakat desa secara keseluruhan. Memang, ada program-program yang tidak berjalan karena alasan dana.

Namun demikian warga Desa Mattiro Bone Pulau Bontosua sangat mengagungkan kepala desa yang terdahulu, karena sosok kepala desa yang terdahulu memang memiliki andil besar dalam memajukan desa. Dari penuturan beberapa informan kunci mereka lebih mempercayai kinerja pemerintah desa yang terdahulu dibandingkan dengan pemerintah desa yang sekarang.

Terkait dengan pemerintahan yang sekarang (baru sekitar 7 bulan) terutama dalam pelaksanaan program/proyek yang dilaksanakan di desa, ada kelompok informan yang kurang begitu percaya pada pemerintah desa karena segala sesuatu dilakukan secara tertutup tanpa melibatkan semua aparat pemerintahan desa dan juga masyarakat. Informan yang tidak percaya pada pemerintah desa sekarang beralasan bahwa kebutuhan masyarakat desa tidak terpenuhi, dan bahkan selama kades ini tidak pernah ada pembangunan apa-apa; semua adalah hasil dari kades sebelumnya. Kades yang sekarang kurang bergaul dengan masyarakat. Langkah untuk memelihara kedamaian dan kepercayaan antar warga dan pemerintah desa salah satunya satunya adalah pemerintah desa harus tanggap, harus ada musyawarah, misalnya satu bulan sekali, dan harus melibatkan masyarakat.

Hasil yang menunjukkan tingkat kepercayaan terhadap pemerintahan di Desa Mattiro Bone, Pulau Bontosua ini dapat dilihat dari hasil pengolahan data dari diagram berikut ini: 


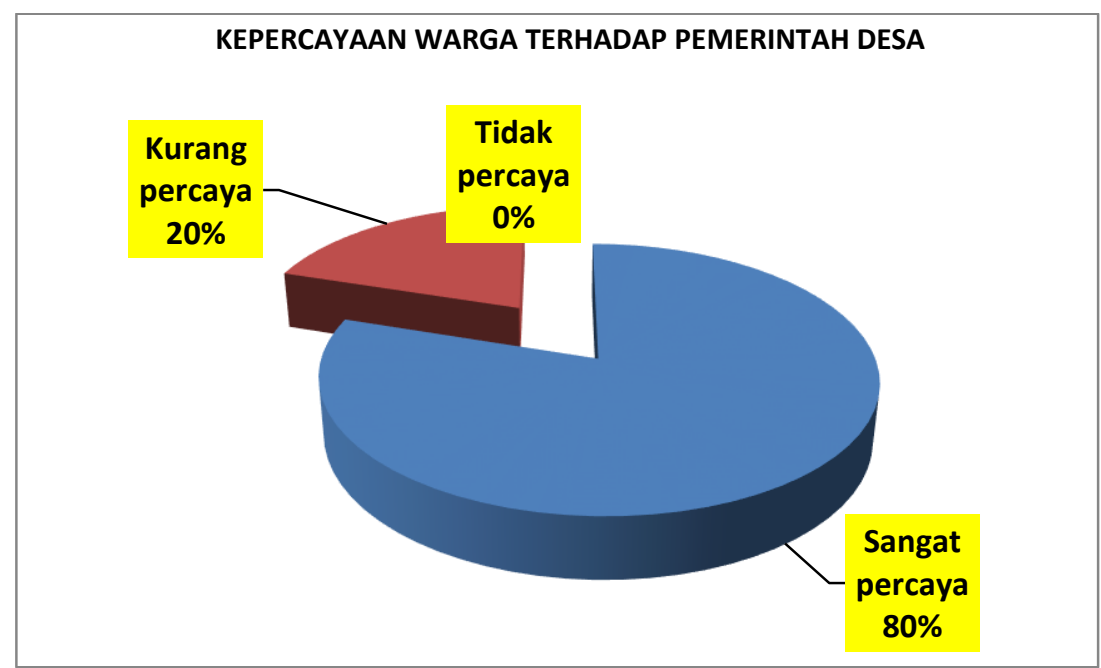

Diagram 2. Tingkat Kepercayaan Terhadap Pemerintahan

Merujuk pada data diagram diatas, terlihat bahwa tingkat kepercayaan masyarakat terhadap pemerintahan desa khususnya terhadap Kepala Desa masih sangat kuat, hal itu dapat dilihat dari total 15 responden $80 \%$ diantaranya mempercayai sepenuhnya kewenangan desa kepada Kepala Desa. Meskipun dari beberapa hasil wawancara mendalam pada beberapa warga menunjukkan ketidakpuasan masyarakat terhadap Kepala Desa terpilih, namun warga tetap mempercayakan pihak pemerintahan Desa dalam urusan yang terkait dengan kemajuan dan pemberdayaan masyarakat Desa Mattiro Bone.

Penjelasan lain untuk melihat bagaimana kapital sosial terkait kepercayaan (trust) pada warga Desa Mattiro Bone, yakni kepercayaan warga kepada tokoh masyarakat setempat. Kepercayaan (trust) warga kepada pemerintah menjadi modal penting bagi keberlangsungan pemerintahan pada suatu wilayah dalam rangka pelaksanaan program-program pembangunan. Demikian pula kepercayaan warga terhadap tokoh masyarakat juga sangat menentukan berjalannya roda pemerintahan dan program pembangunan yang akan dan sedang dilaksanakan. Sebab bagi masyarakat perdesaan seorang kepala desa disamping sebagai kepala pemerintahan atau pemimpin juga sekaligus sebagai tokoh masyarakat yang selalu menjadi panutan dan wajib dipatuhi oleh setiap anggota masyarakat. Pandangan demikian juga berlaku bagi komunitas yang berada dan hidup di Pulau Bontosua.

Berdasarkan hasil wawancara dengan informan, tokoh masyarakatnya dalam hal ini imam masjid di Desa Mattiro Bone masih mendapat kepercayaan di masyarakatnya. Hal tersebut sebagaimana dikemukakan salah satu informan berinisial (Rw), yaitu:

"kami disini sebenarnya sudah saling mengenal, jadi dalam hal kepemimpinan desa siapapun yang terpilih dan memimpin desa ini kami percaya kalau dia pasti orangnya baik dan dapat 
dipercaya."(Wawancara, 20 mei 2017).

Meskipun tokoh masyarakat ini mendapat kepercayaan dari masyarakatnya, namun terdapat juga masyarakat yang tidak sepenuhnya percaya dengan tokoh masyarakatnya khususnya Imam Desa. Seperti yang dikemukakan oleh salah seorang informan berinisial (S), sbb:

"Kalau Imam Desa disini jarang ikut kalau ada musyawarah, beliau juga jarang berbaur sama masyarakat disini. Tapi, kami tetap hormati beliau sebagai orang tua kami”. (Wawancara, 20 mei 2017).

Hasil yang menunjukkan tingkat kepercayaan masyarakat terhadap tokoh masyarakat di Desa Mattiro Bone, Pulau Bontosua dapat dilihat dari diagram berikut ini:

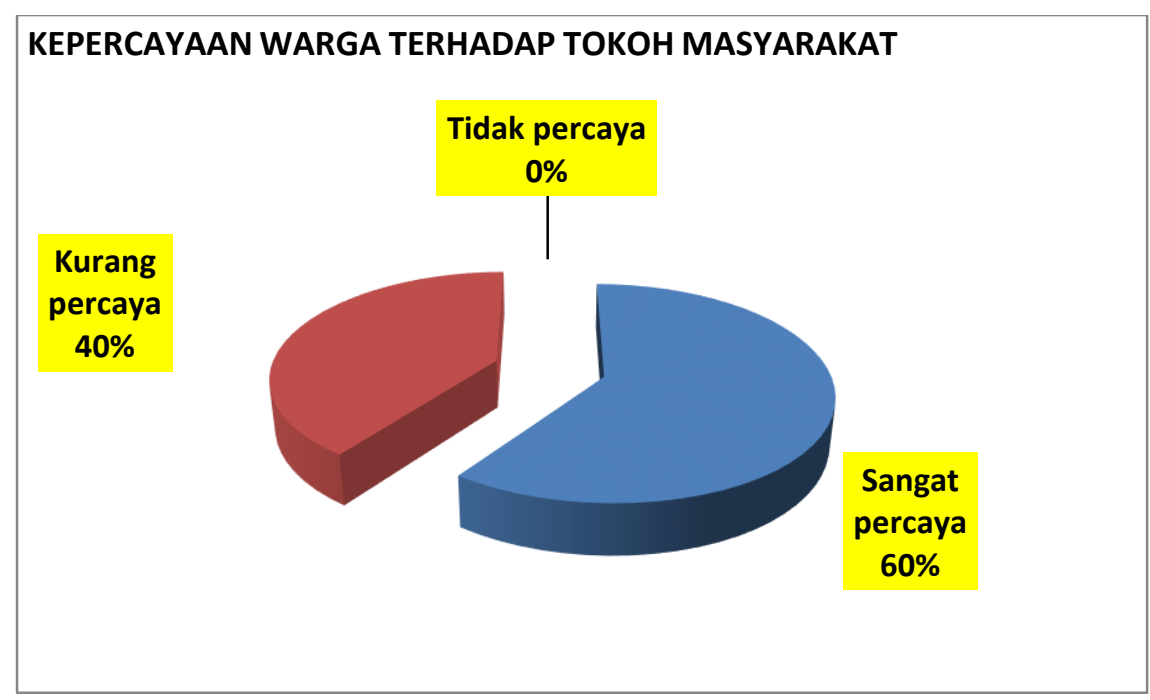

Diagram 3: Tingkat Kepercayaan Terhadap Tokoh Masyarakat

Berdasarkan data dari diagram di atas, dapat dilihat bahwa masih terdapat masyarakat yang kurang mempercayai tokoh masyarakatnya. Meskipun dari data menunjukkan bahwa masyarakat yang sangat percaya terhadap tokoh masyarakat Desa lebih tinggi dibandingkan yang kurang percaya, namun persentase yang di dapatkan tidak terlalu mencolok. Sehingga dapat dilihat bahwa, cukup banyak masyarakat yang merasa bahwa tokoh masyarakat di Desa Mattiro Bone ini belum mampu menjalankan tanggung jawabnya.

\section{- Kepercayaan (Trust) Antara Punggawa dan Sawi}

Modal sosial komunitas nelayan menciptakan dan membangun jaringan atau linking terhadap pihak yang secara khirarkhi/stratifikasi lebih tinggi, yang artinya modal sosialnya mampu menciptakan kepercayaan dan hubungan timbal-balik antara komunitas nelayan yang strata sosial lebih rendah dengan pihak atau struktur yang lebih tinggi. 
Eksplorasi Ponggawa-Sawi sebagai suatu sistem tradisional di masyarakat pesisir Sulawesi Selatan dibentuk dalam konsep hubungan antara ponggawa dan sawi yang dikenal sebagai hubungan patron dan client. Ponggawa adalah seorang yang mampu menyediakan kapital (sosial dan ekonomi) bagi kelompok masyarakat dalam menjalankan suatu usaha (biasanya berorientasi pada skala usaha penangkapan ikan); sedangkan sawi adalah sekelompok orang yang bekerja pada ponggawa dengan memakai atribut hubungan norma sosial dan persepakatan kerja. Aturan sosial atau hubungan sosial yang dilandasinya lebih banyak tentang system hirarki sosial, kekerabatan keluarga dan perkawinan yang menjadi ciri khas sistem ponggawa-sawi.

Secara historis, punggawa dapat diartikan sebagai pemimpin bagi suatu etnis tertentu. Karena sifatnya lokalitas, maka kekuatan hubungan sosialnya juga ikut terpengaruh, seperti tingginya tingkat kepercayaan dan gantungan harapan oleh pengikutnya (Sawi) kepada Ponggawanya. Hubungan antara superior dan sejumlah inferior didasari oleh pertukaran pelayanan (service) yang tidak seimbang. Malah dikatakan bahwa besarnya nilai pertukaran antara Ponggawa dan Sawi lebih banyak disandarkan oleh besarnya perhatian atau pemberian yang terjadi. Pengikat hubungan norma ini lebih banyak ditentukan oleh fungsi atau peran Ponggawa sebagai figur utama untuk semua Sawinya, termasuk pinjaman keuangan dan perlindungan atau kesediaan menyediakan bantuan pada saat dibutuhkan. Bagi seorang sawi, tanggungan biaya hidup dan keperluan-keperluan merupakan bantuan yang tidak semata berdimensi ekonomis. Bantuan demikian, meskipun dalam bentuk hutang merupakan mekanisme mempertahankan kehidupan di atas level survive dari pola subsistens. Setiap kali sawi dan keluarganya membutuhkan sesuatu secara mendadak, punggawa selalu tampil sebagai penolong yang menyelamatkan. Nilai yang harus dibayar oleh sawi bukan hanya material dari bantuan tadi, tetapi juga imbalan hutang budi yang menyertainya. Seperti dinyatakan oleh salah seorang informan berinisial (M), yaitu:

"Kalau saya butuh uang biasanya saya meminjam ke punggawa sawi, nanti beliau yang potong dari hasil tangkapan melaut. Kalau istri butuh bahan makanan lain kayak sayur, tepung, sama tempe, istri saya ke punggawa untuk meminjam karena cuma beliau yang sering ke kota untuk beli bahan. Punggawa yang sediakan keperluannya kami, baru kami pinjam ke beliau, untuk dibayarnya itu dipotong dari hasil saya melaut. Tapi kadang saya minta ke punggawa supaya jangan dulu dipotong sama utang, beliau juga tidak memaksa supaya harus selalu dibayar".(Wawancara, 20 mei 2017).

Sejalan dengan pernyataan informan $(\mathrm{M})$ di atas, informan berinisial ( $\mathrm{Rb})$ juga menyatakan, bahwa: 
"Suami saya berkerja sama punggawa sawi, hasil dari melaut biasanya dibayar kalau ikan sudah dijual ke kota. Suami dapat upah itu sudah dipotong dengan biaya operasional kapal. Saya sama suami sudah terlalu percaya sama punggawa, kayak kalau saya butuh uang saya pinjam ke beliau. Kalau saya butuh beras sama sayuran atau bahan yang lain yang titip ke beliau karena beliau yang biasa ke kota untuk belanja. Biayanya itu dipotong dari hasil melautnya suami. Beliau tidak pernah memaksa supaya saya selalu bayar utang, kadang saya minta kalau upahnya suami tidak dipotong dulu sama utang saya, beliau juga tidak bakalan potong upahnya suami”, (Wawancara, 20 mei 2017).

Merujuk pada hasil penelitian terlihat bahwa hubungan antara punggawa dan sawi bersifat sukarela dan karena sudah terjalin sangat lama maka secara tidak langsung kekerabatan mereka juga semakin kuat. Tingkat kepercayaan yang terjalin diantara keduanya juga terjalin sangat tinggi. Ponggawa dengan status sosial dan kewajiban sosialnya akan terus menyediakan bahan kebutuhan hidup, misalnya beras atau bahan pangan lainnya kepada sawinya sampai sawi ini dapat menunjukkan tingkat loyalitas yang lebih tinggi dengan cara pengabdian atau mencarikan sawi untuk ponggawanya yang biasanya mempunyai sumber usaha lainnya. Bentuk hubungan inilah yang memperkuat norma kepatuhan atau loyalitas dari sawi kepada ponggawanya, sebaliknya bentuk inilah yang menjadi dasar dalam mempertahankan sawi untuk tetap bekerja kepada ponggawa. Yang terpenting dalam hubungan ini adalah tidak diinginkannya berakhir dengan kondisi konflik kepentingan yang melanggar norma yang ada di dalam masyarakatnya. Hal ini sejalan dengan yang dinyatakan oleh salah seorang informan yang berinisial ( $\mathrm{Sr}$ ) yang mana suaminya merupakan salah satu punggawa di Pulau Bontosua, sbb:

"Suami saya itu punggawa disini, biasanya dia menjualkan ikan hasil melautnya nelayan ke Makassar baru nanti di bagi hasilnya sama nelayan, itu sudah dipotong sama biaya operasional kapal sama uang makan. Nelayan biasanya pinjam uang sama saya, mereka membayar pake hasil tangkapannya, terserah mereka mau bayar berapa, atau mau dibayar langsung atau dicicil. Kalau dia bilang potong saja dari hasil melaut yaa saya potong, tp kalau dia bilang janganmih dulu dipotong yaa saya tidak potong. Biasanya juga istri-istri nelayan kalau butuh sesuatu kayak beras, sayur, atau bahan yang lain, mereka pergi ke saya karena saya yang biasanya ke kota untuk belanja itu semua bahan. Nanti mereka yang ambil sama saya, baru mereka bayar pake hasil melaut suaminya. Saya tidak pernah merasa khawatir selalu dipinjami, karena kita sudah saling percaya apalagi kita sudah lama bersama-sama jadi saya yakin kalau mereka berutang pasti mereka akan bayar biarpun itu dibayar sedikit-demi sedikit". (Wawancara, 20 mei 2017).

Dengan demikian, jalinan hubungan antara punggawa dan sawi lebih terbentuk hubungan banyak benang. Hubungan yang terjalin tidak terbatas pada hubungan kerja semata, yakni di mana seorang punggawa mempekerjakan beberapa orang sawi, akan tetapi dalam pola hubungan tersebut terjalin pula suatu hubungan sosial yang lebih bersifat intern antara punggawa dengan sawinya.

Hasil yang menunjukkan bahwa adanya hubungan tingkat kepercayaan yang tinggi antar punggawa dan sawi di Pulau Bontosua ini dapat dilihat dari hasil pengisian kuesioner yang telah diisi 
oleh responden, yang hasilnya dapat dilihat dalam diagram berikut ini:

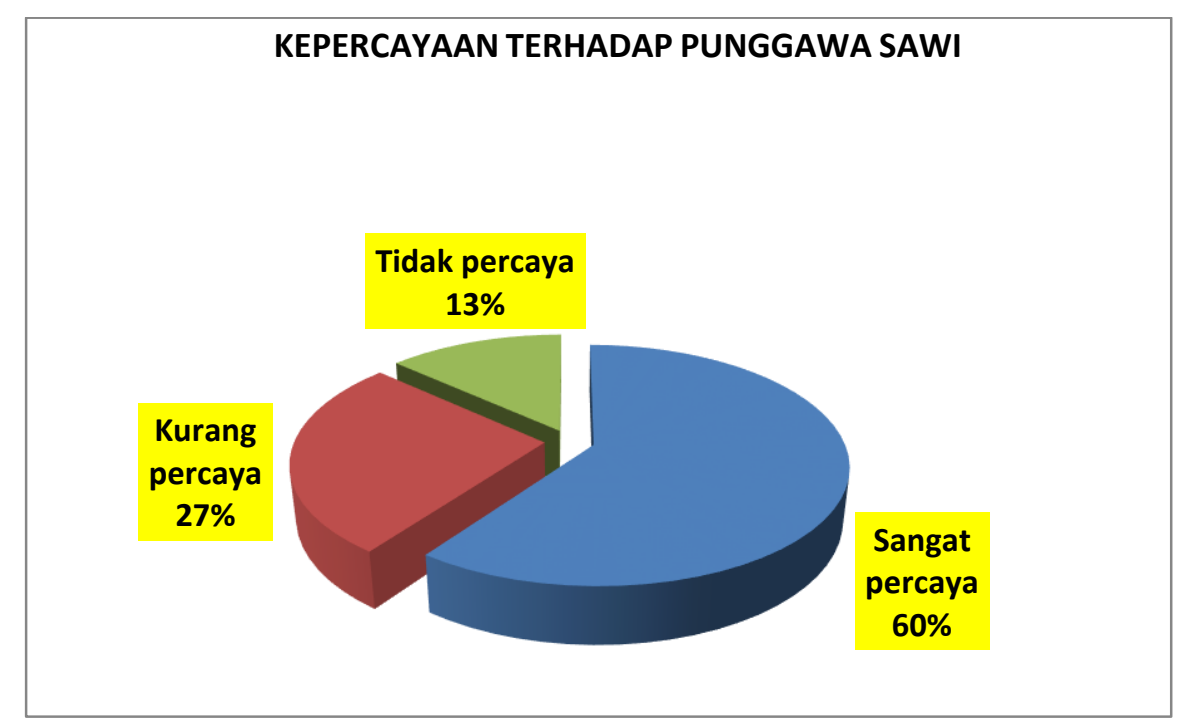

Diagram 4: Tingkat Kepercayaan Sawi Terhadap Punggawa

Diagram diatas mencoba menjelaskan bagaimana tingkat kepercayaan kelompok sawi di Desa Mattiro Bone terhadap punggawa dengan merujuk pada beberapa variabel, diantaranya: sikap saling menghargai, kesiapan punggawa dalam membantu masalah perekonomian sawi, dan kejujuran dari masing-masing pihak. Berdasarkan data dari diagram di atas, dapat dilihat bahwa tingkat kepercayaan sawi terhadap punggawanya termasuk tinggi. Hal ini dapat dapat dilihat bahwa dari 15 responden yang berpartisipasi, $62 \%$ diantaranya masih sangat percaya terhadap punggawanya.

Ini menunjukkan bahwa tingkat kepercayaan sawi terhadap punggawa sangat tinggi. Tingginya kepercayaan kelompok sawi terhadap punggawa juga menunjukkan bagaimana bentuk ketergantungan sawi yang tinggi terhadap punggawanya.

\section{KESIMPULAN}

Berdasarkan pembahasan penelitian sebelumnya maka dapat disimpulkan bahwa Masyarakat desa nelayan Pulau Bontosua pada umumnya memiliki modal sosial trust yang masih kuat dan terjaga. Hal tersebut terbukti dengan adanya kesalingpercayaan diantara warganya. Sementara, modal sosial yang dimiliki masyarakat setempat merupakan sumber daya sosial yang dapat dimanfaatkan untuk melakukan pemberdayaan berbasis modal sosial. 


\section{DAFTAR PUSTAKA}

Abdullah, Suparman, 2014. Modal Sosial dalam Komunitas Nelayan yang Mengalami Diskontinyuitas Sosial Kasus Kampung Nelayan Kelurahan Untia dan Pulau Lae-Lae. Makassar: Disertasi.

Anwar J, Sakaria, dan Lala M, Kolopaking, dkk, 2013. Dampak Intervensi Negara dan Penetrasi Pasar terhadap Perubahan Kapital Sosial pada Komunitas Nelayan Pulau-Pulau Kecil. Jurnal LIPI: Bandung.

Arisandi, Herman, 2015. Buku Pintar Pemikiran Tokoh-Tokoh Sosiologi dari Klasik Sampai Moderen: Biografi, Gagasan dan Pengaruh terhadap Dunia. Yogyakarta: IRCiSoD.

Coleman, James. S. 1998. Social Capital in the Ccreation of Human Capital. The American Journal Sociology (http://en.bookfi.net/)

Creswell, J. W, 2010. Research Design: Pendekatan Kualitatif, Kuantitatif dan Mixed. Yogyakarta: Pustaka Pelajar.

Field, John, 2011. Modal Sosial. Yogyakarta: Kreasi Wacana.

Fukuyama, Francis, 2015. Trust: Kebajikan Sosial dan Penciptaan Kemakmuran. Yogyakarta: Qalam

Hasbullah, J. 2006. Sosial Kapital: Menuju Keungguln Budaya Manusia Indonesia. Jakarta: MR-United Press

Irawan, Rudi. (ed.) dkk. 2011. "Pendidikan Nilai-Nilai Kecakapan Hidup Punggawa dan Sawi Dalam Sistem Sosial Ekonomi Masyarakat Nelayan Etnis Bugis Perantauan di Kota Bandarlampung”. Economy \& Education, Vol. 8 No. 2 November 2011

Mawarni, A. 2010. Modal Sosial dalam Pembangunan Pasca Bencana. Diakses dari http://www.pspk.ugm.ac.id/artikel-terbaru/81-pentingnya-modal-sosial-dalampembangunan-pasca-bencana.html

Mustafa, Muh. Dalvi. 2015. Hubungan Kerja Punggawa-Sawi dalam Perikanan Ikan Terbang di Kabupaten Takalar. Tesis. Yogyakarta: Universitas Gadjah Mada

Santosa. 2014. Pengembangan Masyarakat Berbasis Kearifan Lokal. Yogyakarta: Pustaka Pelajar.

Satori, Djam'an, dan Aan, Komariah, 2013. Metodologi Penelitian Kualitatif. Bandung: Alfabeta.

Ritzer, George, dan Douglas, J. Goodman, 2010. Tori Sosiologi: dari Teori Sosiologi Klasik Sampai Perkembangan Mutakhir Teori Sosial Postmodern. Yogyakarta: Kreasi Wacana. 